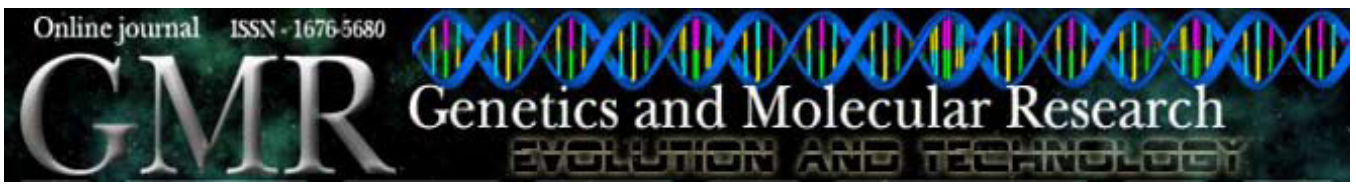

\title{
Cytogenetic findings in Serbian patients with Turner's syndrome stigmata
}

\author{
V.A. Djordjević1, J.V. Jovanović1, S.B. Pavković-Lučić ${ }^{2}$ D.D. Drakulić, \\ M.M. Djurović ${ }^{4}$ and M.D. Gotić ${ }^{1}$ \\ ${ }^{1}$ Clinic of Hematology, Clinical Center of Serbia, Belgrade, Serbia \\ ${ }^{2}$ Faculty of Biology, University of Belgrade, Belgrade, Serbia \\ ${ }^{3}$ Institute of Molecular Genetics and Genetic Engineering, \\ University of Belgrade, Belgrade, Serbia \\ ${ }^{4}$ Clinic of Endocrinology, Clinical Center of Serbia, Belgrade, Serbia \\ Corresponding author: V.A. Djordjević \\ E-mail: djvesna.kcs@gmail.com
}

Genet. Mol. Res. 9 (4): 2213-2221 (2010)

Received August 17, 2010

Accepted September 30, 2010

Published November 9, 2010

DOI 10.4238/vol9-4gmr953

\begin{abstract}
Cytogenetic findings are reported for 31 female patients with Turner's syndrome. Chromosome studies were made from lymphocyte cultures. Non-mosaicism 45,X was demonstrated in 15 of these patients, whereas only three were apparently mosaic. Eight patients showed nonmosaic and four patients showed mosaic structural aberrations of the $\mathrm{X}$-chromosome. One non-mosaic case displayed a karyotype containing a small marker chromosome. Conventional cytogenetics was supplemented by fluorescence in situ hybridization (FISH) with an X-specific probe to identify the chromosomal origin of the ring and a 1q12-specific DNA probe to identify de novo balanced translocation $(1 ; 9)$ in one patient. To our knowledge, this is the first finding of karyotype $45, \mathrm{X}, \mathrm{t}(1 ; 9)$ (cen;cen)/46,X,r(X),t(1;9)(cen;cen) in Turner's syndrome. The same $\mathrm{X}$-specific probe was also used to identify a derivative chromosome in one patient.
\end{abstract}

Key words: Chromosomal abnormalities; Turner's syndrome 


\section{INTRODUCTION}

Turner's syndrome is characterized by short stature, gonadal dysgenesis, and anatomic malformations, including pterygium colli, congenital heart disease, renal anomalies, and cubitus valgus (Turner et al., 1938). Turner's syndrome phenotype is attributed to hemizygosity for genes that are normally expressed in both the active and inactive X-chromosomes in females (Park et al., 1999). According to recent reports, only about half of all Turner's syndrome patients are really monosomic for the whole X-chromosome, while the other half are represented by a heterogeneous group with different structural abnormalities of the sex chromosome (Kuznetzova et al., 1995). Most of them are confined to structural abnormalities of the X-chromosome. The other group of these patients has a mosaic karyotype with the second cell lines carrying numerical or structural sex chromosome anomalies (Gicquel et al., 1992). Detailed clinical and cytogenetic analysis of these patients can provide new information on the developmental effects of different chromosomal segments and their participation in normal and abnormal development.

Complex comparative clinical, cytogenetic, and molecular analyses are also important to determine the nature of derivative and marker chromosomes because of the high risk of malignancy in dysgenetic gonads, owing to the presence of Y-chromosome material (Petrovic et al., 1992; Page, 1994).

Small marker and derivative chromosomes represent a difficult task for cytogenetic analysis by routine classical methods. However, the combination of cytogenetic and molecular techniques enables us to solve this problem quite efficiently and to establish the origin of derivative and marker chromosomes in patients with Turner's syndrome.

Balanced translocations are very rare events in Turner's karyotype. To the best of our knowledge, four cases of monosomy X associated with balanced Robertsonian translocation t(13;14) (Laszlo et al., 1984; Salamanca et al., 1985; Krajinovic et al., 1994; Silva et al., 2006) and one previous case of Turner's syndrome with familial balanced translocation $t(1 ; 2)$ (q32;q21)mat (Kondo et al., 1979) have been reported until now.

In this report, 31 patients with Turner's syndrome stigmata with different karyotypes were studied. Besides cytogenetics, we used fluorescence in situ hybridization (FISH) to examine 2 patients for precise karyotyping and identification of the origin of the ring chromosome and de novo balanced translocation in the karyotype of one patient, and a derivative chromosome in the karyotype of another.

\section{MATERIAL AND METHODS}

\section{Patients}

Since 1990, 31 patients with monosomy X in the different karyotypes (Table 1) have been analyzed in the Laboratory of Cytogenetics and Molecular Genetics, Institute of Hematology, Clinical Center of Belgrade, Serbia. The criteria for inclusion in the study were female phenotype, short stature, delayed or lack of sexual maturation, and complete or partial loss of a sex chromosome in at least some cells.

\section{Cytogenetics}

Cytogenetic analysis was carried out on metaphases obtained from phytohemagglu- 
tinin-stimulated peripheral lymphocytes using a standard procedure. Chromosomes were examined with modified Giemsa staining HG-banding technique, which was described previously in detail (Novak et al., 1994). The karyotypes were presented in accordance with the guidelines of the International System for Human Cytogenetic Nomenclature (ISCN) (Shaffer et al., 2009).

\section{Molecular cytogenetics}

Protocol No. 1 was applied to patients whose mosaic karyotype showed $t(1 ; 9)$ and a ring chromosome (Figure 2). Specifically, FISH was performed on metaphase chromosomes prepared from peripheral blood by a standard technique. To confirm de novo balanced translocation between chromosomes 1 and 9 , a subcentromeric DNA probe specific for chromosome 1 (1q12-21) was used. A tandemly repeated alphoid DNA sequence, DXZ $\alpha$, localized predominantly at the centromeric region of the X-chromosome (Xq11-13), was used to confirm the origin of the ring chromosome. Both of these DNA probes were labeled with biotin-14-dATP using BioNick Labeling System, and the protocol previously described by Djordjevic et al. (2008) was applied.

Protocol No. 2 was applied to patients whose karyotype showed structural abnormality of the X-chromosome (Figure 3). The probe specific for the centromeric region of the Xchromosome was labeled with biotin-14-dATP in a nick translation reaction using a BioNick Labeling System (Gibco-BRL). Approximately $100 \mathrm{ng}$ of the probe was precipitated and dissolved in $16 \mu \mathrm{L}$ hybridization buffer consisting of 50\% formamide, $10 \%$ dextran-sulfate, $1 \%$ SDS, $1 \mathrm{X}$ Denhardt's, $2 \mathrm{X}$ SSC and $0.04 \mathrm{M}$ sodium phosphate, $\mathrm{pH}$ 7.0. The probe was denatured for $10 \mathrm{~min}$ at $65^{\circ} \mathrm{C}$ and kept on ice. The target DNA was denatured in $70 \%$ formamide/2X SSC at $65^{\circ} \mathrm{C}$ for $3 \mathrm{~min}$, quenched immediately in cold $70 \%$ ethanol, dehydrated through an ethanol series $(70,90,90,95 \%)$ and air-dried. Afterward, the probe was placed on a slide, sealed under a coverslip with rubber cement, and incubated in a humidified box at $37^{\circ} \mathrm{C}$ overnight. After removal of coverslips in $2 \mathrm{X} \mathrm{SSC}$ at room temperature, the slides were washed twice, first in $50 \%$ formamide/2X SSC, and then in $2 \mathrm{X} \mathrm{SSC}$ for $10 \mathrm{~min}$ at $42^{\circ} \mathrm{C}$. The slides were incubated in TNFM (4X SSC, $0.05 \%$ Tween $20,5 \%$ non-fat milk) for $20 \mathrm{~min}$ at $37^{\circ} \mathrm{C}$. After incubation with Fluorescein Avidin DCS (Vector Laboratories), the slides were washed in 4X SSC/0.05\% Tween 20 for $5 \mathrm{~min}$ at $42^{\circ} \mathrm{C}$ and then with $10 \mathrm{X}$ PBS for $5 \mathrm{~min}$ at room temperature, and airdried. The slides were mounted in $0.4 \mathrm{mg} / \mathrm{mL}$ DAPI (diamidino phenylindole), counterstained in Vectashield Antifade Buffer and viewed under an Olympus BX51 fluorescent microscope with appropriate filters for detection of fluorescein and the DAPI, and the Cytovision 3.1 software (Applied Imaging Corp.) was used for analysis.

\section{RESULTS}

Conventional cytogenetic analysis was carried out in 31 patients with features of Turner's syndrome. Karyotypes of patients are shown in Table 1 . The most common was monosomic karyotype (15/31 or $48.4 \%)$. In $3 / 31$ patients $(9.7 \%)$ a loss of $\mathrm{X}$ in mosaic form was observed. Aberration i(Xq) was present in $7 / 31$ (22.6\%), while $\mathrm{r}(\mathrm{X})$ was found in $3 / 31$ $(9.7 \%)$ patients. Structural aberrations of $\mathrm{X}$-chromosome were present as $\operatorname{del}(\mathrm{Xp})$ in $1 / 31$ $(3.2 \%)$ and $t(X ; 1)$, also in $1 / 31(3.2 \%)$. Aneuploid karyotype with +mar chromosome was 
observed in $1 / 31(3.2 \%)$ patients.

In one patient with $\mathrm{r}(\mathrm{X})$ in the mosaic karyotype, balanced translocation between chromosomes 1 and 9 with a breakpoint in centromeres was observed. Mitoses of both cell lines $(45, \mathrm{X} / 46, \mathrm{Xr}(\mathrm{X}))$ are shown in Figure $1\left(\mathrm{~A}_{1}, \mathrm{~A}_{2}\right)$.

\begin{tabular}{|c|c|c|c|}
\hline Description & Karyotype & Number of patients & $\%$ \\
\hline X-complete and homogeneous monosomies & $45, \mathrm{X}$ & $15 / 31$ & $48.4 \%$ \\
\hline X-mosaic monosomies & $45, \mathrm{X} / 46, \mathrm{XX}$ & $3 / 31$ & $9.7 \%$ \\
\hline $\mathrm{X}$-isochromosome & 46,X,i(Xq) & $5 / 31$ & $16.1 \%$ \\
\hline $\mathrm{X}$-mosaic isochromosome & $45, \mathrm{X} / 46, \mathrm{X}, \mathrm{i}(\mathrm{Xq})$ & $2 / 31$ & $6.5 \%$ \\
\hline X-ring chromosome & $46, \mathrm{X}, \mathrm{r}(\mathrm{X})$ & $2 / 31$ & $6.5 \%$ \\
\hline $\mathrm{X}$-mosaic ring chromosome & $45, \mathrm{X}, \mathrm{t}(1 ; 9) / 46, \mathrm{X}, \mathrm{r}(\mathrm{X}), \mathrm{t}(1 ; 9)$ & $1 / 31$ & $3.2 \%$ \\
\hline X-deletion chromosome & 45,X/46,XX,del(Xp) & $1 / 31$ & $3.2 \%$ \\
\hline X-structural abnormalities & $46, X, t(X ; 1)$ & $1 / 31$ & $3.2 \%$ \\
\hline$\underline{X \text {-other chromosome abnormalities }}$ & $47, \mathrm{XX},+\mathrm{mar}$ & $1 / 31$ & $3.2 \%$ \\
\hline
\end{tabular}

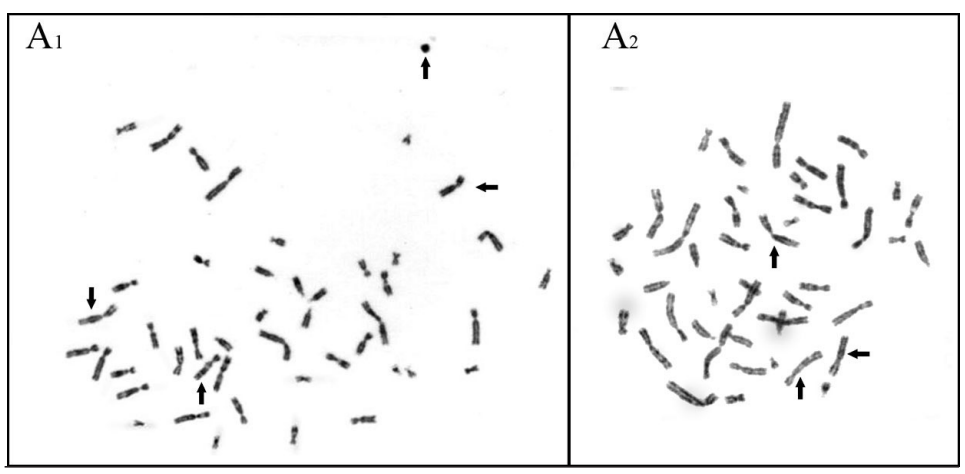

Figure 1. Peripheral blood karyotype of the patient with mosaic $r(X)$ and balanced $t(1 ; 9)$. $\left(A_{1}\right)$ HG-banded metaphase shows cell line 46,X,r(X),t(1;9). Arrows indicate balanced chromosomes 1 and $9, r(X)$ and $\mathrm{X}$-chromosome. $\left(\mathrm{A}_{2}\right) \mathrm{HG}$-banded metaphase shows cell line 45,X,t $(1 ; 9)$. Arrows indicate balanced chromosomes 1 and 9 and $\mathrm{X}$-chromosome.

To determine the origin of the ring chromosome, FISH analysis was performed with the DXZ $\alpha$ probe, specific for the centromeric region of the X-chromosome. To confirm the assumption that it is a balanced translocation between chromosomes 1 and 9, FISH analysis with 1q12-specific DNA probe was also performed. Two HG-banded mitotic chromosome spreads, as well as the results of metaphase FISH applied in these preparations, are shown in Figure 2.

It was confirmed that the ring chromosome originates from the $\mathrm{X}$-chromosome (Figure $\left.2 \mathrm{~A}_{1}, \mathrm{~A}_{2}\right)$, and that two chromosomal derivatives, $\operatorname{der}(1)$ and $\operatorname{der}(9)$, were products of balanced translocation between chromosome 1 and chromosome 9 (Figure $2 \mathrm{~B}_{1}, \mathrm{~B}_{2}$ ). The cytogenetic result of the last patient was $45, \mathrm{X}, \mathrm{t}(1 ; 9)(\mathrm{cen} ; \mathrm{cen})[30] / 46, \mathrm{X}, \mathrm{r}(\mathrm{X}), \mathrm{t}(1 ; 9)(\mathrm{cen} ; \mathrm{cen})[2]$.

Cytogenetic analysis of the constitutive karyotype of both parents of this patient showed that their karyotypes were normal. Analysis confirmed that the balanced $t(1 ; 9)$ in the karyotype of our patient was de novo aberration in $\mathrm{r}(\mathrm{X})$ mosaic Turner's karyotype. 

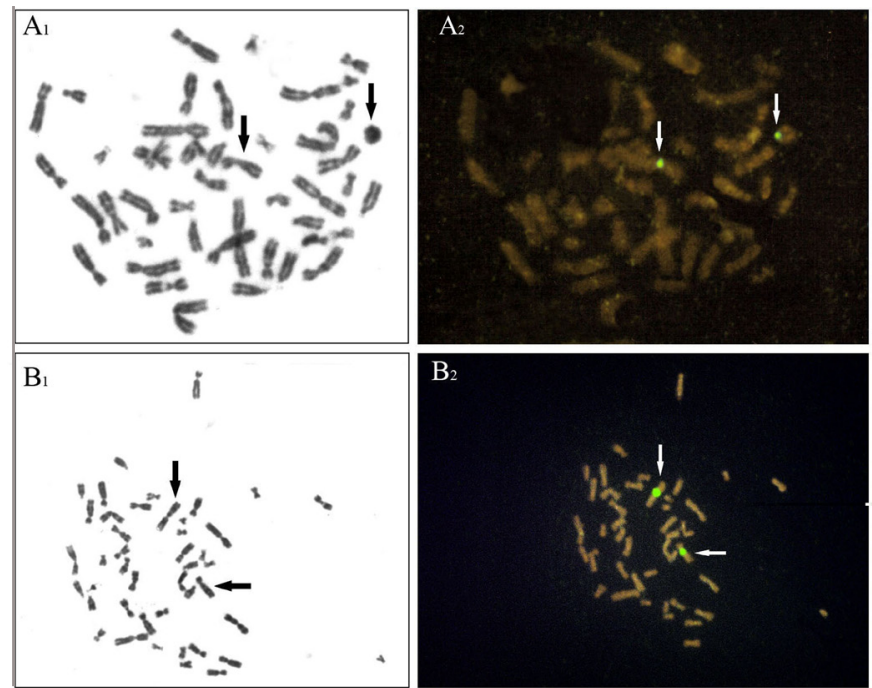

Figure 2. Peripheral blood karyotype and FISH analysis results of the patient with mosaic $r(X)$ and balanced $t(1 ; 9)$. $\left(A_{1}\right)$ HG-banded metaphase and $\left(A_{2}\right)$ FISH with the probe specific for centromeric region of the X-chromosome (green), showing the signals present on both normal X-chromosome and $\mathrm{r}(\mathrm{X})$ (arrows). ( $\mathrm{B}_{1}$ ) HG-banded metaphase and $\left(\mathrm{B}_{2}\right)$ FISH with the probe specific for 1q12 region (green), showing the signals present on both normal and translocated chromosome 1 (arrows).

In another patient, in which karyotype translocation between the X-chromosome and chromosome 1 was observed, FISH analysis with the DNA probe specific for the X-chromosome was performed, so $t(X ; 1)$ was confirmed by molecular cytogenetics. Partial karyotype of this patient, as well as the results of FISH analysis, is shown in Figure $3\left(\mathrm{~A}_{1}, \mathrm{~A}_{2}\right)$.
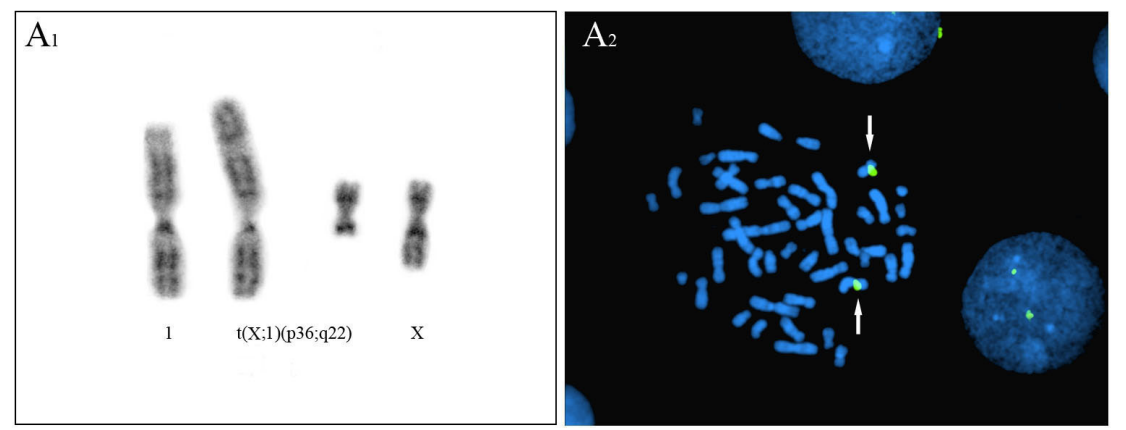

Figure 3. Partial karyotype and FISH analysis results of the patient with $t(1 ; \mathrm{X})$. ( $\left.\mathrm{A}_{1}\right)$ Partial karyotype, showing $\mathrm{t}(\mathrm{X} ; 1)(\mathrm{p} 36 ; \mathrm{q} 22)$. ( $\left.\mathrm{A}_{2}\right)$ FISH with the probe specific for the centromeric region of the X-chromosome (green), showing the signals present on both normal and translocated X-chromosome (arrows).

\section{DISCUSSION}

Turner's syndrome is the most common sex chromosomal abnormality in females, affecting an estimated 3\% of all females conceived (Chander and Ahmed, 2001). It is well known 
that two basic hypotheses on the manifestation of Turner's syndrome can be considered; first, the existence of two X-chromosomes for the survival of early human XO conceptuses, and, second, haploinsufficiency or imbalance of the same gene products in non-activated homologous regions of the X- and Y-chromosomes (Kuznetzova et al., 1995).

Monosomy X $(45, \mathrm{X})$ may represent $1-2 \%$ of all human conceptuses (De La Chapelle, 1990). In spite of the mild phenotypic abnormalities in live-born $45, X$ individuals compared with live-born autosomal trisomies, more than $99 \%$ of 45 , X embryos are aborted in early pregnancy (Hook and Warburton, 1983). Hook and Warburton speculated that 45,X fetuses who survive to live birth are cryptic mosaics. They hypothesized that these patients had a second cell line in some organs or tissues in which a double dose of the same locus or loci of the long arm of the X-chromosome is necessary for fetal survival. Because of differences in ascertainment, the prevalence rate of 45,X Turner's syndrome varies between 40 and $60 \%$ in different studies (Held et al., 1992). The detection of chromosomal mosaicism depends on several factors, including the number of cells examined, the number and type of tissues studied, the culture techniques employed, and whether in vivo or in vitro selection against one of the cell line occurs (Held et al., 1992).

In our study, we investigated the karyotypes of patients with Turner's syndrome only from peripheral blood lymphocytes (for technical reasons), and compared our findings with the results of single-center studies that included a large number of patients (87-150). In our group of patients (Table 1), the most common karyotype was monosomic 45,X, found in $48.4 \%$, i.e., $15 / 31$ patients. Mosaic karyotype 45,X/46,XX, was only present in $9.7 \%(3 / 31)$ patients. Structural aberrations of X-chromosome, such as $\mathrm{i}(\mathrm{Xq}), \mathrm{r}(\mathrm{X}), \operatorname{del}(\mathrm{Xp}), \mathrm{t}(\mathrm{X} ; 1)$, were found in $38.7 \%$ patients $(12 / 31)$, a large percentage for this group of patients. Aneuploid karyotype with marker chromosome was observed in one female (1/31 or $3.2 \%)$.

Table 2 summarizes the chromosome findings in lymphocytes of patients with Turner's syndrome reported in the literature, as well as our results. The data include studies by Palmer and Reichmann (1976), Hall et al. (1982), Ranke et al. (1983), Park et al. (1983), Held et al. (1992), and present the series of the patients reported, respectively. By comparing our findings with results of these studies, we conclude that, although our group of patients was the smallest, the results were roughly similar. The largest deviation was in the mosaic karyotypes such as $\mathrm{X} / \mathrm{XXX}$ or $\mathrm{X} / \mathrm{XX} / \mathrm{XXX}$. In our group, there were no such karyotypes, while in the other

\begin{tabular}{|c|c|c|c|c|c|c|}
\hline Author & $\begin{array}{c}\text { Palmer and } \\
\text { Reichmann (1976) }\end{array}$ & $\begin{array}{l}\text { Hall et al. } \\
\text { (1982) }\end{array}$ & $\begin{array}{l}\text { Ranke et al. } \\
\text { (1983) }\end{array}$ & $\begin{array}{l}\text { Park et al. } \\
\text { (1983) }\end{array}$ & $\begin{array}{l}\text { Held et al. } \\
\text { (1992) }\end{array}$ & This study \\
\hline Patients studied & $\mathrm{N}=110$ & $\mathrm{~N}=127$ & $\mathrm{~N}=150$ & $\mathrm{~N}=116$ & $\mathrm{~N}=87$ & $\mathrm{~N}=31$ \\
\hline Karyotype 45,X & $58.2 \%$ & $55.0 \%$ & $60.0 \%$ & $61.2 \%$ & $20.7 \%$ & $48.4 \%$ \\
\hline \multicolumn{7}{|l|}{ Mosaicism } \\
\hline $\mathrm{X} / \mathrm{XX}$ & $8.2 \%$ & $13.4 \%$ & $14.7 \%$ & $11.2 \%$ & $17.2 \%$ & $9.7 \%$ \\
\hline $\mathrm{X} / \mathrm{X}, \mathrm{i}(\mathrm{Xq})$ & $11.2 \%$ & $4.7 \%$ & $5.3 \%$ & $7.8 \%$ & $12.6 \%$ & $6.5 \%$ \\
\hline $\mathrm{X} / \mathrm{X}, \mathrm{r}(\mathrm{X})$ & $5.5 \%$ & $3.9 \%$ & $4.7 \%$ & $1.7 \%$ & $3.5 \%$ & $3.2 \%$ \\
\hline $\mathrm{X} / \mathrm{XXX}$ or $\mathrm{X} / \mathrm{XX} / \mathrm{XXX}$ & $1.8 \%$ & $0.8 \%$ & $1.3 \%$ & $0.9 \%$ & $6.9 \%$ & - \\
\hline $\mathrm{X} / \mathrm{X},+\operatorname{mar}$ & - & $0.8 \%$ & - & - & $18.4 \%$ & $3.2 \%$ \\
\hline $\mathrm{X} / \mathrm{XY}$ & $5.4 \%$ & $3.1 \%$ & - & $2.6 \%$ & $2.3 \%$ & - \\
\hline \multicolumn{7}{|l|}{ Structural aberrations } \\
\hline $\mathrm{X}, \mathrm{i}(\mathrm{Xq})$ & $7.3 \%$ & $5.5 \%$ & $6.0 \%$ & $6.0 \%$ & $5.7 \%$ & $16.1 \%$ \\
\hline $\mathrm{Xdel}(\mathrm{Xp})$ & $0.9 \%$ & $0.8 \%$ & $1.3 \%$ & $2.6 \%$ & $2.3 \%$ & $3.2 \%$ \\
\hline$X \operatorname{Xel}(X q)$ & - & $1.6 \%$ & - & $1.7 \%$ & $3.5 \%$ & - \\
\hline Others & $0.9 \%$ & $3.3 \%$ & $0.7 \%$ & $0.9 \%$ & $1.2 \%$ & $3.2 \%$ \\
\hline
\end{tabular}


studies they were present (Palmer et al., 1976; Hall et al., 1982; Ranke et al., 1983; Park et al., 1983; Held et al., 1992). Mosaicism X/XY was absent in our report, as well as in the study of Ranke and colleagues (1983). Also, del(Xq) was not present in our patients, while it was found in three of the five studies mentioned above (Hall et al., 1982; Park et al., 1983; Held et al., 1992). Karyotype $\mathrm{Xi}(\mathrm{Xq})$ was the most common in our group of patients (16.1\%), comparable to other studies (Palmer and Reichmann, 1976; Hall et al., 1982; Ranke et al., 1983; Park et al., 1983; Held et al., 1992).

Particularly interesting was the karyotype of our patient with a balanced translocation $\mathrm{t}(1 ; 9)$ in all mitoses, and $\mathrm{r}(\mathrm{X})$ chromosome in mosaic form.

A ring chromosome is formed when breaks occur at both ends of a chromosome and proximal ends rejoin. The acentric fragment is usually lost and partial monosomy results. In practice, ring chromosomes induce complex mitotic events with variable duplication, deficiency and unpredictable phenotypic expression. It has been noted that $\mathrm{r}(\mathrm{X})$ chromosome cases are phenotypically different according to size of the ring, reflecting the amount of deletion of both short and long arms (Chander and Ahmed, 2001). The smaller the ring, the greater the deletion is, with closer resemblance to classic 45,X Turner's phenotype (Collins et al., 1994). Some authors felt that the $\mathrm{r}(\mathrm{X})$ chromosome patients lacked many of the classic Turner's syndrome features and that the majority are not karyotyped until the age of 11 years, usually because of pubertal failure (Dennis et al., 1993; Collins et al., 1994). Also, others believed that the phenotype is more severely affected than expected in classical Turner's syndrome (Migliori et al., 1991; Van Dyke et al., 1992; Dennis et al., 1993; Cantu et al., 1995).

Our patient was 19 years old, with primary amenorrhea, sexual infantilism and short stature. The external genitalia were female, but immature; breast development was absent. The ovarian ultrasound displayed only bilateral streak gonads.

Cytogenetic analysis showed a ring chromosome in the karyotype of this patient. FISH confirmed that the ring chromosome originated from the X-chromosome and that the cell line $46, X, r(X)$ was present in $12 \%$, while cell line $45, X$ was present in $88 \%$ of peripheral blood lymphocytes. Also, cytogenetic analysis showed the presence of balanced translocation $\mathrm{t}(1 ; 9)$ in all mitoses, and FISH analysis confirmed it.

Balanced translocations in 45 , X karyotype are very rare. Four previous cases of monosomy $\mathrm{X}$ associated with a translocation $\mathrm{t}(13 ; 14)$ have been reported. Salamanca et al. (1985) reported a case of maternally inherited $\mathrm{t}(13 ; 14)$, but did not investigate the parental origin of the $\mathrm{X}$-chromosome non-disjunction. Laszlo et al. (1984) reported a patient, her mother and sister, who all had a $\mathrm{t}(13 ; 14)$. Krajinovic et al. (1994) found that both X-chromosomes and the $t(13 ; 14)$ were paternally inherited in one of their patients. Silva et al. (2006) reported a patient who had both translocation and X-chromosome that were demonstrated to be maternally inherited. All of these studies reported the association between balanced Robertsonian translocations and Turner's syndrome. To our knowledge, only one patient was reported with Turner's syndrome and familiar balanced translocation. Kondo et al. (1979) reported a patient whose karyotype was 45,X,t(1;2)(q32;q21)mat.

As far as we know, our patient is a unique case of Turner's syndrome whose karyotype is the result of mosaicism of cells with monosomy $\mathrm{X}$ and cells with $\mathrm{r}(\mathrm{X})$. In both cell lines, de novo balanced translocation $\mathrm{t}(1 ; 9)$ (cen;cen) was present, since both her parents had a normal karyotype. In this example, in karyotype 45,X/46,X,r(X) in combination with unrelated balanced translocation, we can conclude that there is no causal-consequential relationship between autosomal and sex chromosome abnormalities. 
$\mathrm{X}$; autosome chromosomal translocations are also rare in the karyotype of Turner's syndrome. Omar et al. (1999) published three cases of Turner's syndrome with X; autosome chromosomal translocation. The karyotype of two female patients was 46,X,der(9)t(9;X)(q11.2; 22.3$)$. This abnormal chromosomal complement results in a loss of the short arm of the X-chromosome and a gain of an extra copy of the long arm of chromosome 9. One patient had a karyotype with balanced translocation of the same chromosomes $46, \mathrm{X}, \mathrm{t}(9 ; \mathrm{X})(\mathrm{q} 11.2 ; \mathrm{q} 22.3)$. X;autosome chromosomal translocation was found in one of our patients. Her karyotype was 46,X,t(1;X) (p36;q22), and FISH analysis confirmed the presence of both X-chromosome centromeres.

We are convinced by the present results, as well as by data of other authors, that only the combined application of cytogenetic and molecular techniques can provide adequate chromosomal analysis in patients with different chromosomal complement in Turner's syndrome karyotype.

\section{ACKNOWLEDGMENTS}

Research supported by the Ministry of Science and Technological Development, Republic of Serbia (DD Grant \#143028).

\section{REFERENCES}

Cantu ES, Jacobs DF and Pai GS (1995). An atypical Turner syndrome patient with ring X chromosome mosaicism. Ann. Clin. Lab. Sci. 25: 60-65.

Chander NV and Ahmed EFEM (2001). Turner's syndrome variant with three cell line mosaicism and ring X chromosome $(45, \mathrm{X} / 46, \mathrm{Xr}(\mathrm{X})(\mathrm{p} 21 \mathrm{q} 25) / 46, \mathrm{Xx})$ in a Saudi patient. Bahrain Med. Bull. 23: 42-44.

Collins AL, Cockwell AE, Jacobs PA and Dennis NR (1994). A comparison of the clinical and cytogenetic findings in nine patients with a ring (X) cell line and $1645, \mathrm{X}$ patients. J. Med. Genet. 31: 528-533.

De La Chapelle A (1990). Sex Chromosome Abnormalities. In: Principles and Practice of Medical Genetics (Emery AEH and Rimoin DL, eds.). Edinburgh Chudchill, Livingstone, 193-215.

Dennis NR, Collins AL, Crolla JA, Cockwell AE, et al. (1993). Three patients with ring (X) chromosomes and a severe phenotype. J. Med. Genet. 30: 482-486.

Djordjevic V, Dencic-Fekete M, Jovanovic J, Drakulic D, et al. (2008). Pattern of trisomy 1q in hematological malignancies: a single institution experience. Cancer Genet. Cytogenet. 186: 12-18.

Gicquel C, Cabrol S, Schneid H, Girard F, et al. (1992). Molecular diagnosis of Turner's syndrome. J. Med. Genet. 29: $547-551$.

Hall JG, Sybert VP, Williamson RA, Fisher NL, et al. (1982). Turner's syndrome. West. J. Med. 137: 32-44.

Held KR, Kerber S, Kaminsky E, Singh S, et al. (1992). Mosaicism in 45,X Turner syndrome: does survival in early pregnancy depend on the presence of two sex chromosomes? Hum. Genet. 88: 288-294.

Hook EB and Warburton D (1983). The distribution of chromosomal genotypes associated with Turner's syndrome: livebirth prevalence rates and evidence for diminished fetal mortality and severity in genotypes associated with structural X abnormalities or mosaicism. Hum. Genet. 64: 24-27.

Kondo I, Hamaguchi H, Matsura A, Nakajima H, et al. (1979). A case of Turner's syndrome with familial balanced translocation $\mathrm{t}(1 ; 2)(\mathrm{q} 32 ; \mathrm{q} 21)$ mat. J. Med. Genet. 16: 321-323.

Krajinovic M, Ivanovic K, Mestroni L, Diklic V, et al. (1994). Parental origin of the X chromosome in a patient with a Robertsonian translocation and Turner's syndrome. J. Med. Genet. 31: 255-256.

Kuznetzova T, Baranov A, Schwed N, Ivaschenko T, et al. (1995). Cytogenetic and molecular findings in patients with Turner's syndrome stigmata. J. Med. Genet. 32: 962-967.

Laszlo J, Bosze P, Gaal M and Toth A (1984). A case of 44,X streak gonad syndrome combined with familial balanced 13/14 translocation. Acta Med. Hung. 41: 223-227.

Migliori MV, Bartolotta E, Maurizi M, Bonazzi P, et al. (1991). A report of 2 cases of Turner's syndrome with a ring X chromosome. Minerva Pediatr. 43: 605-609.

Novak A, Kruskic M, Ludoski M and Jurukovski V (1994). Rapid method for obtaining high-quality chromosome banding 
in the study of hematopoietic neoplasia. Cancer Genet. Cytogenet. 74: 109-114.

Omar HA, Hummel M, Jones EA and Perkins KC (1999). Hypoplastic external genitalia in association with X;autosome chromosome translocation. J. Pediatr. Adolesc. Gynecol. 12: 161-164.

Page DC (1994). Y chromosome sequences in Turner's syndrome and risk of gonadoblastoma or virilisation. Lancet 343: 240.

Palmer CG and Reichmann A (1976). Chromosomal and clinical findings in 110 females with Turner syndrome. Hum. Genet. 35: 35-49.

Park E, Bailey JD and Cowell CA (1983). Growth and maturation of patients with Turner's syndrome. Pediatr. Res. 17: 1-7.

Park JP, Brothman AR, Butler MG, Cooley LD, et al. (1999). Extensive analysis of mosaicism in a case of Turner syndrome: the experience of 287 cytogenetic laboratories. College of American Pathologists/American College of Medical Genetics Cytogenetics Resource Committee. Arch. Pathol. Lab. Med. 123: 381-385.

Petrovic V, Nasioulas S, Chow CW, Voullaire L, et al. (1992). Minute Y chromosome derived marker in a child with gonadoblastoma: cytogenetic and DNA studies. J. Med. Genet. 29: 542-546.

Ranke MB, Pfluger H, Rosendahl W, Stubbe P, et al. (1983). Turner syndrome: spontaneous growth in 150 cases and review of the literature. Eur. J. Pediatr. 141: 81-88.

Salamanca F, Buentello L, Sanchez J and Armendares S (1985). A patient with 44 chromosomes. Ann. Genet. 28: 130-132.

Shaffer LG, Slovak ML and Campbell LJ (2009). An International System for Human Cytogenetic Nomenclature. S. Karger, Basel.

Silva AL, Lima RLLF, Ribeiro LA and Moretti-Ferreira D (2006). X monosomy and balanced Robertsonian translocation in a girl with Turner Syndrome. Genet. Mol. Biol. 29: 47-48.

Turner HH (1938). A syndrome of infantilism, congenital webbed neck, and cubitus valgus. Endocrinology 23: 566-574.

Van Dyke DL, Wiktor A, Palmer CG, Miller DA, et al. (1992). Ullrich-Turner syndrome with a small ring X chromosome and presence of mental retardation. Am. J. Med. Genet. 43: 996-1005. 